\title{
PRODUCTION OF BIOGAS FROM CATTLE WASTE AT LOW TEMPERATURE
}

\author{
T.Y. Yeole \\ N.S. Deshmukh \\ K.L. Lapsiya \\ D.R. Ranade \\ Agharkar Research Institute, India
}

\begin{abstract}
Production of Biogas from cattle waste and other biomass is now considered as one of the major routes to obtain gaseous fuel for sustainable development. In tropical countries like India thousands of rural families in villages are using 3 to $5 \mathrm{M}^{3}$ biogas plants to suffice their daily cooking fuel need. All these plants are run on cattle waste. Since these plants are operated at ambient temperatures, effect of temperature variation affects daily gas yield. The effect becomes very prominent during winter season. In general about $50-60 \%$ reduction in daily biogas yield is observed when ambient temperature is around $15^{\circ} \mathrm{C}$ as compared to that produced at around 30 $35^{\circ} \mathrm{C}$. A low cost and simple to operate technique to enhance biogas yield from the biogas plant during winter season shall help to get optimum biogas yield from these plants during the winter season. We thought of a simple technique of filtering the digested effluent slurry of biogas plant through a triple layer muslin cloth to obtain a filtrate, hence-forth called as clarified digested slurry (CDS), rich in cell mass and then adding it back to the biogas plant along with the influent slurry. Experiments were carried out on $25 \mathrm{~L}$ capacity cattle dung biogas plant operated at $15^{\circ} \mathrm{C}$ to see effect of recirculation of CDS. Addition of 25 and $40 \% \mathrm{v} / \mathrm{v}$ CDS in daily influent resulted in $15 \%$ and $37 \%$ increase in daily biogas yield. Recirculation of $40 \% \mathrm{v} / \mathrm{v}$ CDS supplemented with Diammonium phosphate(DAP) increased the biogas yield by $75 \% \mathrm{v} / \mathrm{v}$. In another experiment use of clarified rumen fluid (CRF) to prepare influent slurry and added exclusively for one day enhanced the daily biogas yield by $70 \% \mathrm{v} / \mathrm{v}$ for a period of two months. Popular daily wears in India called cotton dhoti or cotton sari can be used for the filtration of the slurry.
\end{abstract}

\section{KEYWORDS}

Biogas production; Low temperature; Cattle dung; Clarified digested slurry

\section{INTRODUCTION}

In India cattle dung is commonly used as a substrate for biogas production. Over 2.8 million biogas plants are set up in the country [1]. One major problem in operating and obtaining 
optimum biogas yield from these plants is lowering of efficiency of anaerobic digestion and biogas yield in winter season when the ambient temperature goes below $20{ }^{\circ} \mathrm{C}$.

Attempts were made to maintain the temperature of these biogas plants in winter season by providing insulation, heating or circulating hot water outside the plants. However, these methods are impracticable and are not economical. These attempts have failed to enhance biogas production in winter season. Researchers have tried to adapt the microorganisms at low temperature and use these in biogas plants $[2,3,4,5,6,7]$. However, completely satisfactory solution has not been obtained.

One of the alternatives to overcome the loss of efficiency is to increase the number and activity of anaerobic bacteria including methanogens present therein. The effluent slurry of biogas plant running at low temperature is rich in all essential anaerobic bacteria. These microorganisms are exposed to low temperature for 30 days or so, are considered well adapted to $15^{\circ} \mathrm{C}$. With a view to take advantage of temperature adapted microbial cell mass, simple procedure to separate microbial cell mass from the effluent slurry was derived. In this process the effluent slurry was filtered through a triple layer (approximately 20 mesh no.) cotton cloth (muslin cloth), popularly called as dhoti. The filtered slurry was called as clarified digested slurry (CDS) and had total solids (TS) $1.80 \%$ volatile solids (VS) $1.54 \%$ and volatile suspended solids (VSS) $1.50 \%$. The CDS thus had less substrate and more VSS.

\section{METHODS}

\subsection{Biogas Plant}

Biogas plants used in the study were $25 \mathrm{~L}$ capacity, non-stirred, floating dome digester of KVIC design [8]. Three plants were kept and run in the cabinet having constant temperature of $15 \mathrm{a}$.

\subsection{Feed material}

Cattle dung was obtained from one specific nearby dairy. It was diluted with tap water to have $10 \%$ total solids (TS).

\subsection{Experimental set up}

All the plants were run on fresh cattle dung slurry at $15^{\circ} \mathrm{C}$ having 30 day hydraulic retention time (HRT) normally used for biogas plants run on cattle dung in India.

\subsubsection{Effect of recirculation of clarified digested slurry (CDS)}

The effluent slurry from biogas plant was filtered through triple layered muslin cloth, called as 'dhoti' to get homogenous clarified digested slurry hence-forth called as CDS. This retained the active biomass from the effluent slurry adapted at low temperature in the CDS however; the undigested substrate was removed during filtration. The CDS thus obtained contained more VSS.

Experiment was carried out using three-biogas plants.. In one plant $25 \%(\mathrm{v} / \mathrm{v}) \mathrm{CDS}$ was added in daily feed, in second plant $40 \%(\mathrm{v} / \mathrm{v})$ CDS was added in daily feed. Third plant receiving only 


\author{
Kalmar ECO-TECH 05 and \\ The Second Baltic Symposium on Environmental Chemistry \\ KALMAR, SWEDEN, November 28-30, 2005
}

fresh cattle dung slurry served as control. The experiment was carried out over a period of 50 days.

\title{
2.3.2. Effect of supplementation of Diammonium phosphate (DAP) to CDS
}

After completion of the above experiment $80 \mathrm{mg}$ of Diammonium phosphate (DAP) was added in daily feed of one plant having $40 \%$ CDS. In another plant $40 \%$ recirculation of CDS was continued. The control plant in the above experiment was continued as a control for this experiment. The experiment was carried out over a period of 28 days.

\subsubsection{Effect of addition of clarified rumen fluid (CRF)}

For this experiment rumen fluid was obtained from a nearby slaughterhouse and it was clarified as described above and hence- forth called as CRF. The rumen fluid is rich in anaerobic bacteria including methanogens. After clarification the filtrate contained active biomass. Three biogas plants were used. Two experimental plants received $40 \%$ CDS in daily feed. In one of the experimental plants in daily feed instead of water $415 \mathrm{ml}$ of CRF was added one time only. Third plant receiving fresh cattle dung slurry served as the control. Experiment was carried out over a period of 60 days.

\subsection{Analysis}

In all the experiments biogas produced daily was measured with wet gas flow meter (Toshniwal, Chennai) and analyzed for its methane content on gas chromatograph [9]. Volatile Fatty Acids (VFA) were analyzed on a gas chromatograph equipped with flame ionization detector [10] Total solids (TS), VS, VSS were estimated as per the procedures described in Standard methods [11].

\section{RESULTS AND DISCUSSION}

\subsection{Effect of recirculation of CDS}

Results on effect of recirculation of CDS are given in Table 1 and Figure 1 . It is seen from the result that there was $14.6 \%$ and $36.5 \%$ increase in biogas production with recirculation of $25 \%$ and $40 \%(\mathrm{v} / \mathrm{v})$ of CDS, respectively over the control. Methane content in the biogas produced in all the plants was in between 44 to $47 \%$. The pH of the fermenting slurry of these plants was 6.5 7.2, which is favorable for methanogenesis. During preparation of CDS the undigestable substrates are removed and the CDS contained biomass, which is active as well as well adapted to low temperature. It also contains the active extracellular enzymes produced during anaerobic digestion, which ultimately resulted in enhanced biogas production. The results also showed that the increase in biogas production is directly proportional to the volume of CDS added in daily feed. 


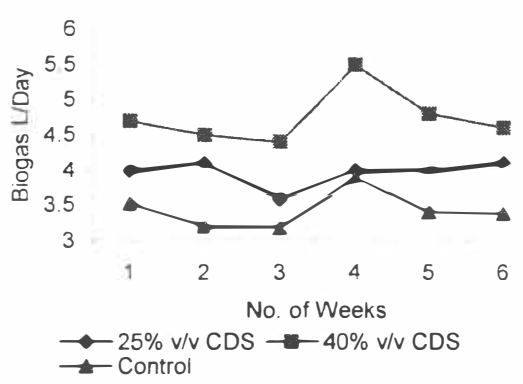

Figure 1. Effect of recirculation of CDS.
Table 1. Effect of recirculation of CDS.

\begin{tabular}{llll}
\hline $\begin{array}{l}\text { Average } \\
\text { Biogas } \\
\text { Produced }\end{array}$ & $\begin{array}{l}\text { With } \\
25 \% \mathrm{v} / \mathrm{v} \\
\mathrm{CDS}\end{array}$ & $\begin{array}{l}\text { With } \\
40 \% \mathrm{v} / \mathrm{v} \\
\mathrm{CDS}\end{array}$ & $\begin{array}{l}\text { Without } \\
\mathrm{CDS} \\
\text { (Control) }\end{array}$ \\
$\begin{array}{l}\text { L/Day } \\
\mathrm{L} / \mathrm{Kg}\end{array}$ & 3.99 & 4.76 & 3.49 \\
dung/Day & 9.5 & 11.3 & 8.3 \\
\% Increase & 14.6 & 36.5 & - \\
Methanea\% & 45.7 & 46.5 & 43.6 \\
\hline
\end{tabular}

\subsection{Effect of supplementation of Diammonium phosphate to CDS}

Results on effect of supplementing DAP with $40 \%$ recirculation of CDS are given in Table 2 and Figure 2. The results showed that merely adding $80 \mathrm{mg}$ DAP daily in the plant having $40 \% \mathrm{CDS}$ resulted in $75 \%$ increase in biogas production over the control. There was no much change in methane content (46-48\%) and $\mathrm{pH}$ of the fermenting slurry (6.5-7). Addition ofaDAP provided nitrogen as well as phosphorus as nutrients to the biomass which ultimately resulted in increase in biogas production by $75 \%$ over the control.

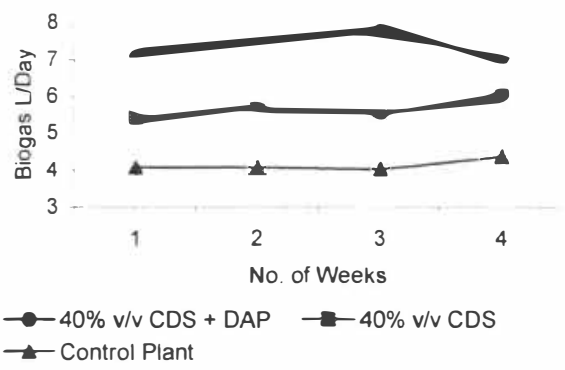

Table 2. Effect of supplementing DAP.

\begin{tabular}{|c|c|c|c|}
\hline $\begin{array}{l}\text { Average } \\
\text { Biogas } \\
\text { Produced }\end{array}$ & $\begin{array}{l}\text { With } \\
40 \% \mathrm{v} / \mathrm{v} \\
\mathrm{CDS} \\
+\mathrm{DAP}\end{array}$ & $\begin{array}{l}\text { With } \\
40 \% \mathrm{v} / \mathrm{v} \\
\text { CDS }\end{array}$ & $\begin{array}{l}\text { Without } \\
\text { CDS } \\
\text { (Control) }\end{array}$ \\
\hline L/Day & 7.23 & 5.65 & $4 . d 2$ \\
\hline $\begin{array}{l}\mathrm{L} / \mathrm{Kg} \\
\text { dung/Day }\end{array}$ & 17.43 & 13.61 & 9.94 \\
\hline$\%$ Increase & 75 & 37.1 & \\
\hline Methane\% & 47.4 & 46.5 & 44.7 \\
\hline
\end{tabular}

Figure 2. Effect of supplementing DAP.

\subsection{Effect of Addition of Clarified Rumen Fluid (CRF)}

The results of effect of addition of CRF are given in Table 3 and Figure 3. Results showed that addition of CRF, once only' enhanced the biogas production by $70 \%$ and the effect remained for a period of 8 weeks. Methane content in biogas of these plants was between 46 to $49 \%$. The pH of the fermenting slurry was $6.5-7.2$. The $\mathrm{CRF}$ contains very active anaerobic bacteria including 


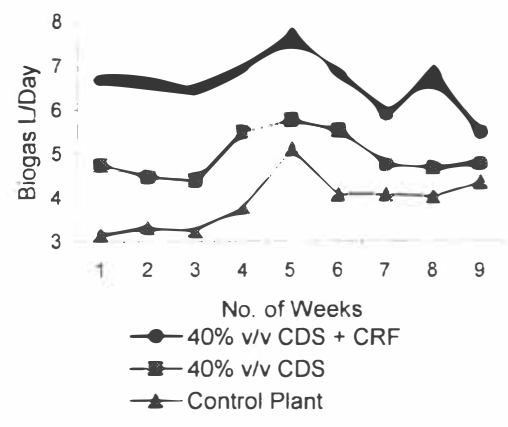

Figure 3. Effect of addition of $C R F$.
Table 3. Effect of addition of $C R F$.

\begin{tabular}{cccc}
\hline $\begin{array}{c}\text { Average } \\
\text { Biogas } \\
\text { Produced }\end{array}$ & $\begin{array}{c}\text { With } \\
40 \% \mathrm{v} / \mathrm{v} \\
\mathrm{CDS} \\
+ \\
\mathrm{CRF}\end{array}$ & $\begin{array}{c}\text { With } \\
40 \% \mathrm{v} / \mathrm{v} \\
\mathrm{CDS}\end{array}$ & $\begin{array}{c}\text { Without } \\
\mathrm{CDS} \\
(\text { Control })\end{array}$ \\
& & & \\
\hline L/Day & 6.64 & 4.96 & 3.90 \\
L/Kg & 16.01 & 11.96 & 9.40 \\
dung/Day & & & \\
\% Increase & 70 & 27.5 & \\
Methanea $\%$ & 49.1 & 47.0 & 45.6 \\
\hline
\end{tabular}

methanogens and the active enzymes, produced in the rumen, which ultimately resulted in increase in biogas production. To have a constant increase in biogas production one has to add the $\mathrm{CRF}$ at an interval of every 8 weeks.

Thus, there was a definite and significant increase in biogas production due to the recirculation of CDS. The increase is directly proportional to the volume of CDS added in daily feed. Maximum $40 \%$ CDS can be obtained from the daily effluent slurry of the biogas plant. The digested slurry filtered through triple layer of muslin cloth contained more VSS and trace amount of undigested substrates. The bacteria from the effluent slurry retained in CDS could be considered as well adapted to low temperature at which the plants are operated. In addition the CDS might contain extracellular enzymes as well as co-factors required for the active growth of methanogens. The recirculation of CDS enhanced the number of adapted cells in the digester, which resulted in enhancement of overall microbial activity responsible for more biogas production from cattle dung.

When the CDS was supplemented with DAP it provided nitrogen as well as phosphorous as the nutrient to the biomass which increased the number as well as activity of the biomass and resulted in $75 \%$ more biogas over the control. DAP is used as the fertilizer hence it is always available with the farmer and the required quantity can be added in the daily feed to get enhanced biogas production.

The rumen of the animal is rich in anaerobic bacteria including methanogens. The CRF when added in biogas plant enhances the number as well as activity of methanogen. The CRF contains extracellular enzymes and might be providing the co-factors required for the growth of the methanogens, which ultimately enhanced the biogas production, and the effect remains for a period of 8 weeks. To have enhanced biogas production one has to add the CRF to the plant after every 8 weeks. 


\section{CONCLUSIONS}

Using a simple method of filtration of effluent slurry a clarified digested slurry (CDS) rich in bacterial cell mass adapted to low temperature and containing extra cellular enzymes could be obtained. Recirculation of CDS enhances the biogas production at low temperature. Addition of DAP to CDS further improves the gas production. Clarified rumen fluid (CRF) added once in biogas plant with CDS increases the daily biogas production by $70 \% \mathrm{v} / \mathrm{v}$ and the effect remains for a period of 60 days. Thus recirculation of CDS offers a low cost easy to operate and reliable method to enhance biogas production in winter season.

\section{ACKNOWLEDGEMENT}

We thank the Ministry of Non-Conventional Energy Sources, Government of India for financial support for the study.

\section{REFERENCES}

[1] Ministry of Non-Conventional Energy Sources, 2000. Annual Report. MNES, Government of India, New Delhi.

[2] Vineent, W. F., 1988. Microbial ecosystem of Antarctica. University Press, Cambridge.

[3] Zeeman, G., Sutter, K., Vens, T., Koster, M. Wellinger, A., 1988. Psychrophilic digestion of dairy and pig manure: start up procedure of batch, fed-batch and CSTR-type digesters. Biological Waste 26, 15-31.

[4] Kalia, A. K., Kanwar, S., 1989. Temperature profile of biogas plants operating under hilly conditions. Biological Wastes 30, $217-224$.

[5] Meher, K.K., Murty, M. V. S., Gollakota, K.G., 1994. Psychrophilic anaerobic digestion of human waste. Bioresource Technology 50, 103-106.

[6] Rebac, S. J., Ruskova, S., Gerbenrs, J. V., Vanlier, A. J. M., Lettinga, G., 1995. High rate anaerobic treatment of wastewater under psychrophilic conditions. J. Ferment. And Bioeng. 80, 499-506.

[7] Singh, L., Maurya, M. S., Raman, K. V., Alam, S. I., 1995. Production of biogas from night soil at psychrophilic temperature. Bioresource Technology 53, 147-149.

[8] Kunte, D. P., Yeole, T.Y., Chiplonkar, A.S; Ranade, D.R., 1998. Inactivation of Salmonella typhi by high levels of fatty acids during anaerobic digestion. J. Appl. Microbiol. 84, 138142.

[9] Ranade, D. R., Yeole, T. Y., Godbole, S. H., 1987. Production of biogas from market waste. Biomass 13, 147-153.

[10] Yeole, T. Y., Ranade, D. R., Gadre, R. V., 1989. Biogas from liquid waste arising in liver and beef extract production. RERIC International Energy Journal 1 1, 35-39.

[11] APHA, 1992. Standard methods for the examination of water and wastewater, $18^{\text {th }}$ Edition, American Public Health Association (APHA), AWWA, WPCF, Washington, DC. 